\title{
SEAWEED CHRONICLE: SEBUAH PROYEK HIBRIDA ESTETIKA \& INDUSTRI RUMPUT LAUT DI PULAU PARI, KEPULAUAN SERIBU, INDONESIA
}

\author{
Gabrielle Nadine Cahya Mulya ${ }^{1)}$, Alvin Hadiwono ${ }^{2)}$ \\ 1)Program Studi S1 Arsitektur, Fakultas Teknik, Universitas Tarumanagara, gnadinecm@gmail.com \\ 2) Program Studi S1 Arsitektur, Fakultas Teknik, Universitas Tarumanagara, alvinh@ft.untar.ac.id
}

Masuk: 04-07-2021, revisi: 14-08-2021, diterima untuk diterbitkan: 23-10-2021

\begin{abstract}
Abstrak
Sebagai daerah yang berdekatan dengan ibukota Jakarta, Kepulauan Seribu memiliki permasalahan ekosistem alam dan manusia. Dari segi alam, tingginya kadar karbon akibat aktivitas manusia di ibukota menyebabkan pencemaran laut dan rusaknya keseimbangan ekosistem Laut Jawa. Sedangkan dari segi manusia, tingginya ketergantungan masyarakat Kepulauan Seribu terhadap ibukota Jakarta untuk memenuhi kebutuhan sehari-hari menyebabkan kualitas kehidupan dan ekonomi setempat sulit berkembang. Selain itu, Kepulauan Seribu memiliki potensi budidaya rumput laut, namun kurang diminati masyarakat karena nilai jual rendah akibat kurangnya pengetahuan cara mengolah rumput laut. Penulis merancang proyek 'Seaweed Chronicle : Sebuah Proyek Hibrida Estetika \& Industri Rumput Laut' yang bertujuan menyelesaikan permasalahan Kepulauan Seribu, khususnya Pulau Pari, dengan prinsip arsitektur ekologi dan menyatukan fungsi estetika dan industri. Program industri memanfaatkan komoditas rumput laut yang melimpah untuk diolah menjadi barang kebutuhan sehari-hari masyarakat guna meningkatkan kualitas hidup. Penerapan tema 'beyond ecology' berupa program penghayatan estetika rumput laut yang bertujuan mengganti cara pandang manusia agar lebih menghayati dan menghargai keberadaan makhluk lain (bukan hanya sekedar objek yang diperbudak, namun sebagai subjek yang setara dengan manusia) sehingga meningkatkan kepedulian terhadap alam. Rincian program pada proyek adalah workshop industri (pengolahan rumput laut menjadi kertas, plastik, pupuk, material bangunan, dan furniture), galeri penghayatan rumput laut (terdiri dari galeri lukisan, aquarium, penghayatan rumput laut dengan cahaya, gelombang laut, perjalanan waktu, dan refleksi), restoran, panggung edukasi, dan kios penjualan hasil rumput laut. Proyek dapat dinikmati oleh masyarakat Pulau Pari sekaligus menarik wisatawan.
\end{abstract}

Kata kunci : arsitektur ekologi; estetika; industri; rumput laut.

\begin{abstract}
As an area close to Indonesia's capital city, Thousand Island have both nature and human ecosystem problems. From a nature perspective, the high levels of carbon produced by human activities in the capital cause marine pollution and imbalance of the Java Sea ecosystem. Meanwhile, from a human perspective, the high dependence of the people of the Thousand Islands on the capital city to meet their daily needs has made it difficult for the quality of life and the local economy to develop. In addition, the Thousand Islands has potential to grow seaweed, but didn't catch local people's interest because of the low selling value due to a lack of knowledge on how to process seaweed properly. The author designed the 'Seaweed Chronicle: An Industrial and Aesthetic Hybrid Project' which aims to solve the problems of the Thousand Islands, especially Pari Island, with the principles of ecological architecture. The industrial program utilizes an abundance of seaweed commodities to be processed into daily necessities for the community to improve the quality of life. The application of the theme 'beyond ecology' in the form of a program to appreciate the aesthetics of seaweed, which aims to change the human perspective to appreciate and appreciate the existence of other creatures (not just objects that are enslaved, but as subjects that are equal to humans) so as to increase awareness of nature. The program
\end{abstract}


details for the project are industrial workshops (processing seaweed into paper, plastics, fertilizers, building materials, and furniture), seaweed development galleries (consisting of painting galleries, aquariums, seaweed appreciation with light, sea waves, time travel, and reflection), restaurants, educational stages, and stalls selling seaweed products. The project can be enjoyed by the people of Pari Island as well as attracting tourists.

Keywords: aesthetic; ecology architecture; industry; seaweed

\section{PENDAHULUAN}

\section{Latar Belakang}

Jumlah penduduk di Indonesia menduduki peringkat ke-4 di dunia, yaitu sebanyak 260 juta jiwa dengan laju pertumbuhan $1.25 \%$ per tahun (Hasil Sensus Penduduk 2020, 2021). Tingginya jumlah penduduk berarti meningkatnya kebutuhan, sehingga semakin banyak sumber daya alam yang dieksploitasi untuk kepentingan manusia dan menimbulkan kerusakan alam. Salah satunya adalah peningkatan kadar karbon di alam akibat aktivitas manusia. Pada tahun 2016, Indonesia tercatat memproduksi karbon sebanyak 2.15 metric ton, angka tertinggi dibanding tahun-tahun sebelumnya, dan diperkirakan terus meningkat di masa mendatang. Dan dibandingkan seluruh wilayah Indonesia, ibukota Jakarta memproduksi kadar karbon yang lebih tinggi akibat tingginya aktivitas dan mobilitas penduduk. Hal ini berdampak pada ketidakseimbangan ekosistem, salah satunya pengasaman Laut Jawa.

Di Laut Jawa, terdapat Kepulauan Seribu, yang juga memiliki masalah pemenuhan kebutuhan hidup sehari-hari karena terlalu bergantung pada ibukota Jakarta meskipun infrastruktur dan aksesibilitas belum mendukung. Hal ini menyebabkan harga kebutuhan pokok menjadi lebih tinggi dan masyarakat sulit meningkatkan perekonomian, kesejahteraan, maupun kepedulian terhadap alam (Damarjati, 2019). Selain itu, Kepulauan Seribu juga memiliki potensi budidaya rumput laut, salah satu makhluk hidup yang memiliki banyak manfaat, baik untuk mengurangi karbon maupun memenuhi kebutuhan manusia (Gewati, 2019). Namun, budidaya rumput laut belum diminati karena kurangnya pengetahuan dan fasilitas untuk mengolah rumput laut menjadi bahan yang bermanfaat bagi masyarakat. (Wibowo, 2019)

\section{Rumusan Permasalahan}

Kepulauan Seribu mengalami dua jenis permasalahan, yaitu masalah ekosistem alam dan ekosistem manusia. Permasalahan ekosistem manusia adalah perekonomian penduduk yang terhambat karena terlalu bergantung pada ibukota Jakarta, dan menyebabkan kurangnya kepekaan masyarakat terhadap pentingnya menjaga alam. Sedangkan permasalahan ekosistem alam terjadi karena aktivitas penduduk Kepulauan Seribu maupun Jakarta untuk memenuhi kebutuhan sehari-hari yang menghasilkan karbon dan mengakibatkan pengasaman air laut yang berdampak pada keseimbangan ekosistem laut. Padahal, Kepulauan Seribu memiliki potensi yang bisa dikembangkan dalam membantu menyelesaikan kedua permasalahan tersebut, yaitu budidaya rumput laut.

\section{Tujuan}

Tujuan proyek ini adalah sebagai jembatan antara pemenuhan kebutuhan ekosistem alam dan ekosistem manusia dengan mendorong produksi dan pengolahan rumput laut. Proyek arsitektur harus bisa mewadahi kegiatan masyarakat agar dapat mengolah rumput laut menjadi barang kebutuhan sehari-hari, meningkatkan kualitas lingkungan alam, sekaligus mengubah pola pikir dan kebiasaan masyarakat setempat untuk peduli pada lingkungan alam tanpa mengorbankan kepentingan manusia. 


\section{KAJIAN LITERATUR}

\section{Arsitektur Beyond Ecology}

Ekologi didefinisikan sebagai ilmu yang mempelajari tentang ekosistem, yaitu hubungan timbal balik antara makhluk hidup dengan lingkungan di sekitarnya. Dasar ekologi terdiri dari komunitas (biosonos) dan kawasan alam (biotop). Komunitas dan kawasan alam memiliki hubungan timbal balik dan membentuk suatu sistem yang menciptakan suatu keseimbangan sehingga dapat terus berjalan dan berkembang untuk mencapai tujuan tertentu. (Frick, 2006)

Diantara seluruh makhluk hidup di alam, manusia adalah salah satu yang paling dominan. Perkembangan manusia yang pesat melahirkan sistem sosial yang terdiri dari budaya,bahasa, perilaku, ekonomi, kesehatan, teknologi, dan lain-lain. Komponen tersebut saling berhubungan dan timbal balik dan membentuk ekosistem manusia. Arsitektur ekologi berperan sebagai jembatan untuk memenuhi kebutuhan manusia dan alam. Bangunan berfungsi untuk memenuhi kebutuhan manusia, namun juga menciptakan lingkungan yang lebih sedikit mengkonsumsi dan lebih banyak menghasilkan kekayaan alam. Untuk mencapai kondisi tersebut, manusia harus pertama-tama memahami apa yang dibutuhkan alam, mengesampingkan egonya sebagai manusia, dan berkarya dengan cara berpikir ekologi, bukan materialistis. Setelah itu, barulah keberadaan dan kebutuhan manusia 'disisipkan' sehingga dapat memenuhi perkembangan manusia.

Heinz Frick memiliki beberapa prinsip bangunan ekologis yang antara lain : 1) penyesuaian terhadap lingkungan alam setempat, 2) menghemat sumber energi alam yang tidak dapat diperbaharui dan menghemat penggunaan energi, 3) memelihara sumber lingkungan (udara, tanah, air), 4) memelihara dan memperbaiki peredaraan alam, 5) mengurangi ketergantungan kepada sistem pusat energi (listrik, air) dan limbah (air limbah dan sampah), 6) kemungkinan penghuni menghasilkan sendiri kebutuhannya sehari-hari, 7) memanfaatkan sumber daya alam sekitar kawasan perencanaan untuk sistem bangunan, baik yang berkaitan dengan material bangunan maupun untuk utilitas bangunan (sumber energi, penyediaan air).

\section{Rumput Laut}

United Nation Convention on the Law of the Sea (UNCLOS) pada tahun 1982 melaporkan bahwa luas perairan Indonesia adalah 5,8 juta km2 dan didalamnya terdapat $27,2 \%$ dari seluruh spesies flora dan fauna di dunia, salah satunya rumput laut. Rumput laut merupakan salah satu sumber daya hayati yang sangat melimpah di perairan Indonesia, yaitu sekitar 8,6\% dari total biota di laut. Luas wilayah yang menjadi habitat rumput laut di Indonesia mencapai 1,2 juta hektar atau terbesar di dunia (Wawa, 2005). Dari banyaknya variasi spesies rumput laut, yang paling memiliki nilai ekonomis tinggi di Indonesia adalah Eucheuma cottoni dan Sargassum. Sp (Suparmi \& Sahri, 2009)

\section{Syarat Penanaman}

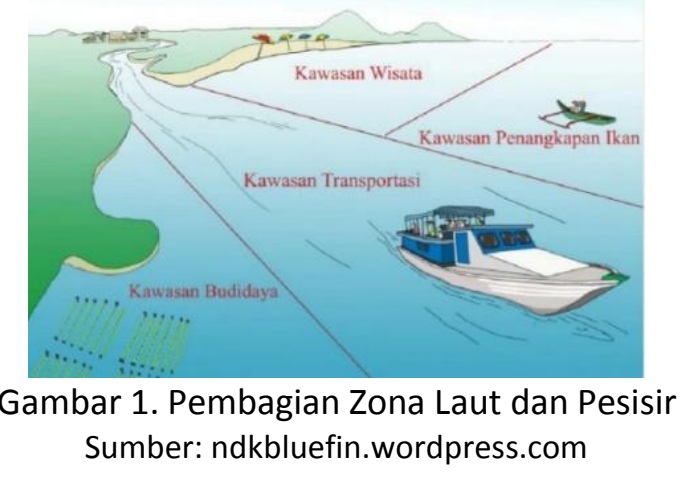


Pemilihan lokasi sesuai dengan tata ruang yang telah ditetapkan oleh pemerintah daerah setempat, contohnya harus sesuai dengan Rencana Zonasi Wilayah Pesisir dan Pulau - Pulau Kecil (RZWP3K) sehingga lokasi budidaya rumput laut tidak bertabrakan dengan kepentingan yang lain seperti pelayaran, penangkapan ikan, pariwisata ataupun daerah industri (NiputuDK, 2015). Selain itu, ada pula standar daerah perairan yang baik untuk menanam rumput laut, yaitu dapat dilihat pada tabel berikut ini:

Tabel 1. Standar Oseanografi untuk Menanam Rumput Laut

\begin{tabular}{ll}
\hline Parameter & Kebutuhan Rumput Laut \\
\hline Suhu $\left({ }^{\circ} \mathbf{C}\right)$ & $\mathrm{S} 1: 24-30$ \\
& $\mathrm{~S} 2: 20-24$ \\
& $\mathrm{~N}:<20 \&>30$ \\
\hline Salinitas (\%) & $\mathrm{S} 1: 30-32$ \\
& $\mathrm{~S} 2: 22-30 \& 32-34$ \\
$\mathrm{~N}:<22 \&>34$ \\
\hline $\mathbf{p H}$ & $\mathrm{S} 1: 6.5-8.5$ \\
& $\mathrm{~S} 2: 4-6.5 \& 8.5-9.5$ \\
& $\mathrm{~N}:<4 \&>9.5$ \\
\hline DO (mg/L) & $\mathrm{S} 1:>6$ \\
& $\mathrm{~S} 2: 4-6$ \\
& $\mathrm{~N}:<4$ \\
\hline Fosfat (mg/L) & $\mathrm{S} 1: 0.07-1.0$ \\
& $\mathrm{~S} 2: 0.02-0.05$ \\
& $\mathrm{~N}:<0.02 \&>1.0$ \\
\hline Nitrat (mg/L) & $\mathrm{S} 1: 0.05-0.06$ \\
& $\mathrm{~S} 2: 0.02-0.04$ \\
& $\mathrm{~N}:<0.02 \&>0.06$ \\
\hline
\end{tabular}

Keterangan: S1: Highly suitable category; S2: Suitable category; N : Less suitable category Sumber: (Rositasari, Rachma, Nurhati, Purbonegoro, \& Yogaswara, 2017) and (Jamaluddin, Syam, Mustarin, \& Rivai, 2020)

\section{Manfaat Rumput Laut}

Di Indonesia, pemanfaatan rumput laut untuk industri dimulai untuk industri agar-agar, alginate, pangan, kosmetik, dan farmasi. Namun seiring perkembangan teknologi, rumput laut ternyata bisa dimanfaatkan untuk berbagai fungsi lain, yaitu:

1. Mengurangi kadar $\mathrm{CO} 2$ di alam

Rumput laut menggunakan fotosintesis untuk mengubah karbon dioksida (CO2) menjadi biomassa rumput laut dan dapat tumbuh 30x lebih cepat dibanding tanaman darat dan seluruh bagian tubuhnya mengalami fotosintesis (tidak seperti tanaman darat yang menyisakan bagian tak produktif seperti akar, ranting, dst). Analisis yang dilakukan oleh $\mathrm{Dr}$ Antoine De Ramon N'Yeurt dari Universitas Pasifik Selatan dan timnya pada tahun 2012 menunjukkan bahwa rumput laut dapat mengurangi kadar $\mathrm{CO} 2$ lebih cepat dan banyak dibanding tumbuhan darat lain. Bahkan, rumput laut juga dapat menjadi carbon storage permanen bila ditenggelamkan ke kedalaman 1000 meter di bawah permukaan laut atau dimanfaatkan sebelum mati/membusuk. (N'Yeurt, Chynoweth, Capron, Stewart, \& Hasan, 2012). Hal ini membuat rumput laut efektif dalam membantu mengurangi pemanasan global. (Chung, et al., 2013)

\section{Furniture}

Rumput laut dapat diolah menjadi furniture, yaitu melalui proses dihancurkan menjadi bubuk, dicampur dengan lem, kertas, dan air, kemudian dicetak menjadi bentuk yang diinginkan. 
Kandungan alginate membuat furniture tahan lama, keras, dan tahan api. Furniture yang dihasilkan bisa berbagai macam, seperti kursi, lampu, tekstil, dll. (Hoogvliet, 2018)

3. Material Bangunan

Berdasarkan studi pustaka yang telah dilakukan, rumput laut dapat diolah menjadi berbagai material bangunan seperti campuran beton (Siddique \& Wahid, 2017), batu bata (Dove, 2014), dan material atap (Larsen, 2018). Penggunaan rumput laut mengurangi penggunaan material tambang dalam bahan bangunan, sehingga menghasilkan produk yang lebih tahan lama, tahan air, dan ramah lingkungan, sekaligus sebagai carbon storage permanen.

4. Plastik Bio-degradable

Rumput laut dapat menjadi material perekayasaan teknologi pembuatan plastik ramah lingkungan (bio-degradable), yaitu berupa kemasan biodegradable dan kemasan edible coating yang digunakan sebagai pembungkus makanan. Kemasan biodegradable diartikan sebagai film kemasan yang dapat di daur ulang dan dihancurkan secara alami. Proses pembuatannya adalah dengan memblender rumput laut tersebut dengan satu liter air secara bertahap sampai menjadi bubur. Kemudian ditambahkan gliserin, diaduk dan dimasak selama sampai mendidih, lalu dicetak pada lembaran film. (Putri, 2019)

5. Kertas

Pada tahun 2004, You Churl H berhasil memproduksi kertas dari bubur ampas rumput laut di laboratorium produk kehutanan Universitas National Chungnam Korea. Rumput laut dihancurkan dan dimasak hingga menjadi pulp (bubuk kertas), dibleaching, dicetak, kemudian dijemur untuk menghasilkan kertas untuk digunakan dalam kegiatan sehari-hari. (You, 2008)

6. Pupuk

Peneliti dari Loka Riset Mekanisasi Pengolahan Hasil Perikanan, Bakti Berlyanto Sedayu mengungkapkan bahwa rumput laut diketahui memiliki kandungan hormon pemacu tumbuh (HPT), di antaranya sitokinin, auksin dan giberelin yang bisa merangsang pertumbuhan pada tanaman. Pupuk rumput laut dibuat dengan proses penghancuran, fermentasi dengan bakteri dan senyawa laktosan, dan diolah menjadi pupuk cair dan padat. (Sedayu, Erawan, \& Assadad, 2014)

\section{Proses Pemahaman Estetika Rumput Laut}

\section{Tahap Penghayatan Estetika Manusia}

Pemahaman estetika manusia tidak terjadi secara langsung sejak dilahirkan, tetapi melalui berbagai tahapan; mulai dari memandang karya seni sebagai objek, menghayatinya lebih dalam sebagai subjek, hingga penghayatan ruang dan waktu. Proses tersebut terbagi atas lima tahap penghayatan (Parsons, 1987), yaitu :

1. Favoritism

Pada tahap ini, manusia memiliki kesadaran yang rendah terhadap keindahan karya seni dan kurang memiliki empati dalam memandang sesuatu dari sudut pandang individu lain. Biasanya ada ketertarikan pada lukisan, warna, dan instalasi yang indah tanpa memperhatikan subjek atau gaya karya seninya.

2. Beauty and Realism

Manusia mulai memandang seni sebagai representasi sesuatu. Karya seni/individu bukan hanya dianggap sebagai objek semata, namun berupa subjek yang memiliki kedudukan setara dengan manusia. Manusia mulai belajar untuk melihat suatu hal dari sudut pandang individu lain.

\section{Expressiveness}

Pada tahap ini, manusia sudah memandang karya seni sebagai subjek, sehingga mereka mulai memperhatikan suatu karya untuk kualitas pengalaman yang dapat dihasilkan. Seolah manusia dan karya seni berjalan bersama untuk berbagi pengalaman di sekitar mereka. Kreativitas, orisinalitas, dan kedalaman perasaan baru dihargai pada tahap ini. Pengalaman dan perasaan yang dialami bisa bervariasi tergantung cara pandang tiap individu terhadap suatu karya. 


\section{Style and Form}

Manusia memaknai sebuah karya seni dalam konteks sosial dibandingkan pencapaian individu saja. Penekanannya adalah bagaimana tekstur, warna, bentuk, ruang, dan gaya dibentuk, karena ini menghubungkan sebuah karya dengan tradisi maupun hubungan suatu gaya dengan sejarah. Makna tradisi bukan hanya sekedar produk budaya saja, namun sebagai perjalanan waktu, dari kejadian masa lampau hingga saat ini.

\section{Autonomy}

Pada tahap terakhir, manusia sudah melakukan penghayatan karya seni secara maksimal, sehingga karya digunakan untuk mengajukan pertanyaan, bukan sebagai penyampaian kebenaran. Seni seolah menjadi cermin agar manusia bisa berkaca dan merefleksikan diri.

\section{Segi Estetika Rumput Laut}

Masyarakat biasanya memahami estetika hanya dari karya seni atau makhluk hidup tertentu, seperti padang bunga dan pemandangan alam. Sementara individu lain seperti rumput laut hanya dilihat dari segi fungsional (manfaat bagi manusia). Padahal, rumput laut juga memiliki keindahan dan segi estetikanya. Zona pesisir (pertemuan antara lautan dan daratan) membuat rumput laut memiliki warna-warna cerah mulai dari hijau berumput dan coklat tanah hingga mawar pucat dan bahkan ungu tua. Segi estetika rumput laut juga dilihat dari bentuk dan tekstur yang beragam, mulai dari bentuk daun berlubang, bilah panjang ramping, hingga bola berisi udara. (Iselin, 2019)

\section{METODE}

Penelitian ini terbagi atas berbagai tahap, yaitu mengumpulkan data, menganalisis dan sintesis data, menyimpulkan data, dan menggunakan hasil perolehan data dalam proyek perancangan untuk menyelesaikan masalah. Pengumpulan data dilakukan dengan studi pustaka dari buku, jurnal, maupun internet yang bertujuan mencari teori dan penelitian tentang rumput laut dan Pulau Pari yang sudah dilakukan untuk mendukung penyelesaian masalah pada tapak. Setelah data terkumpul, penulis melakukan pemilahan dan cross-check antar sumber untuk mendapatkan data yang valid dan berkaitan dengan kebutuhan penelitian.

Selanjutnya, penulis melakukan analisis dari data yang terkumpul. Analisis yang dilakukan seperti analisis lokasi, meliputi penentukan lokasi site di Pulau Pari berdasarkan berbagai pertimbangan meliputi zonasi atau peruntukan wilayah, kependudukan, garis pantai, dan aksesibilitas; analisis tapak yang meliputi bentuk dan dimensi, batas, potensi tapak, pencapaian, view, kebisingan, dan sirkulasi; analisis fungsi bangunan untuk menentukan program yang dapat mengembangkan potensi rumput laut untuk menjawab permasalahan lingkungan dan masyarakat; analisis pengguna yang bertujuan untuk menentukan pengguna proyek dan pola aktivitas yang nantinya akan digunakan sebagai pertimbangan dalam penyusunan tata ruang, zonasi dalam tapak, dan fungsi; analisis ruang yang meliputi kebutuhan ruang, besaran ruang, karakteristik ruang, pencahayaan dan sirkulasi udara, dan suasana ruangan; analisis bentuk bangunan yang sesuai dengan lingkungan sekitar sekaligus menunjukkan identitas rumput laut; serta analisis struktur dan material yang dapat bertahan di tapak dan ramah lingkungan agar tidak menghasilkan banyak karbon, mudah didapat disekitar, dan dapat menjadi pedoman bagi masyarakat sekitar yang akan membangun. Metode desain yang digunakan adalah biomorfik, yaitu menggunakan struktur dari sistem dan anggota gerak makhluk hidup sebagai ide bentuk. Dalam proyek ini, makhluk hidup yang menjadi acuan adalah rumput laut.

\section{DISKUSI DAN HASIL}

Berdasarkan hasil studi pustaka, dapat disimpulkan bahwa rumput laut dapat memiliki dua manfaat, yaitu secara fungsional dan estetikanya. Segi fungsional berarti rumput laut 
dimanfaatkan untuk menghasilkan produk industri yang bermanfaat untuk kesejahteraan manusia dan memperbaiki alam. Sedangkan sisi estetika berarti rumput laut dihayati keberadaanya, dinikmati keindahan dan eksistesiya sebagai makhluk hidup. Kedua manfaat ini menjadi fokus utama pada proyek di Pulau Pari, sehingga pemilihan lokasi, tapak, program, dan perwujudan desain mengarah pada hal tersebut.

\section{Pemilihan Lokasi}

Lokasi yang dipilih adalah area yang memiliki permasalahan dari segi alam dan manusia. Dari segi alam, Teluk Jawa dipilih karena berdekatan dengan ibukota Jakarta, yaitu area dengan aktivitas manusia tinggi dan banyak menghasilkan karbon yang meningkatkan pencemaran dan pengasaman air laut di sekitarnya. Sedangkan dari segi manusia, Kepulauan Seribu dipilih karena berada di area Teluk Jawa dan masyarakatnya memiliki ketergantungan yang tinggi dengan ibukota, padahal aksesibilitas dan infrastruktur antar pulau belum memadai.

Di Kepulauan Seribu, terdapat 4 pulau yang memiliki sudah membudidaya rumput laut, yaitu Pulau Panggang, Pulau Kelapa, Pulau Pari, dan Pulau Tidung. Dari keempat pulau tersebut, Pulau Pari dipilih sebagai lokasi karena luas wilayah untuk budidaya rumput laut paling besar diantara pulau lainnya, yaitu $95.000 \mathrm{~m} 2$, sehingga hasil produksinya berlimpah. Masyarakat setempat sudah menjadikan budidaya rumput laut sebagai bagian dari kehidupan sehari-hari, sehingga proyek arsitektur bisa langsung memfasilitasi rumput laut dari hasil pulau tersebut. Jumlah penduduk Pulau Pari juga tinggi, yaitu 2.990 jiwa, sehingga proyek dapat memenuhi kebutuhan banyak masyarakat. Selain itu, kepadatan penduduk masih rendah, sehingga masih ada ruang bagi masyarakat untuk berkembang.

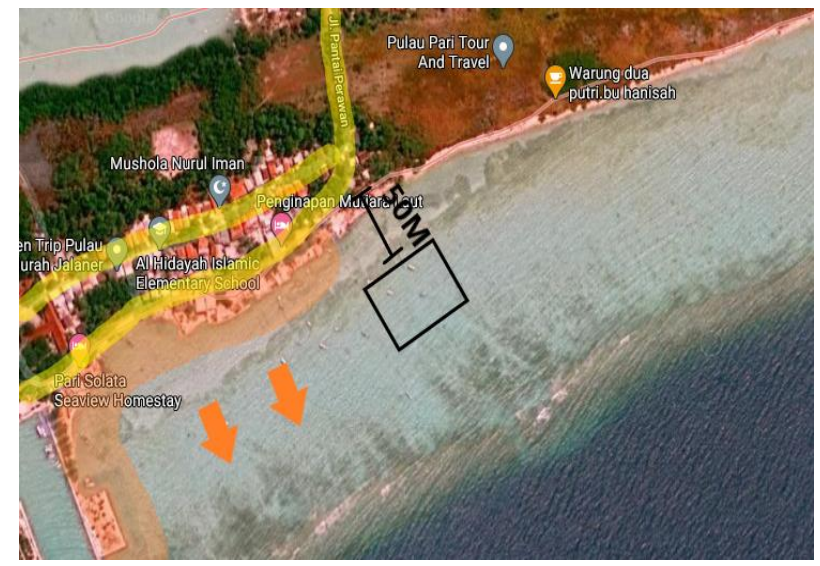

Gambar 2. Lokasi Tapak Terpilih

Sumber: Dokumentasi Pribadi

Tapak terpilih berlokasi di pantai landai dengan kedalaman air $100-400 \mathrm{~cm}$ dengan jarak $275 \mathrm{~m}$ dari Dermaga Pulau Pari, sehingga memudahkan distribusi barang dan pencapaian masyarakat maupun wisatawan. Sesuai dengan Rencana Zonasi Wilayah Pesisir dan Pulau - Pulau Kecil, tapak tidak mengganggu kawasan wisata dan pelayaran exsisting. Tapak terkoneksi langsung dengan habitat rumput laut (air laut) yang berbatasan dengan jalur pelayaran kapal nelayan dan laut lepas. Dari segi oseanografi, kondisi tapak juga memenuhi standar laut untuk penanaman rumput laut, yang dapat dilihat pada tabel berikut : 
Tabel 2. Analisis Kelayakan Karakter Oseanografi Tapak untuk Pertumbuhan Rumput Laut

\begin{tabular}{|c|c|c|c|}
\hline Parameter & Standar & Kondisi Tapak & Kesimpulan \\
\hline \multirow[t]{3}{*}{ Suhu $\left({ }^{\circ} \mathrm{C}\right)$} & S1 : 24-30 & 29.9 & Sangat Baik \\
\hline & S2 : 20-24 & & \\
\hline & $N:<20 \&>30$ & & \\
\hline \multirow[t]{3}{*}{ Salinitas (\%o) } & S1:30-32 & 22.1 & Baik \\
\hline & S2 : $22-30$ \& 32-34 & & \\
\hline & $N:<22 \&>34$ & & \\
\hline \multirow[t]{3}{*}{$\mathrm{pH}$} & S1 : $6.5-8.5$ & 8.40 & Sangat Baik \\
\hline & S2 : 4-6.5 \& 8.5-9.5 & & \\
\hline & $N:<4 \&>9.5$ & & \\
\hline \multirow[t]{3}{*}{$\mathrm{DO}(\mathrm{mg} / \mathrm{L})$} & S1 : >6 & 5.40 & Baik \\
\hline & S2 : 4-6 & & \\
\hline & $\mathrm{N}:<4$ & & \\
\hline \multirow[t]{3}{*}{ Fosfat (mg/L) } & S1 : 0.07-1.0 & 0.05 & Kurang Baik \\
\hline & S2 : 0.02-0.05 & & \\
\hline & $N:<0.02 \&>1.0$ & & \\
\hline \multirow[t]{3}{*}{ Nitrat (mg/L) } & S1 : $0.05-0.06$ & 0.12 & Sangat Baik \\
\hline & S2 : $0.02-0.04$ & & \\
\hline & $N:<0.02 \&>0.06$ & & \\
\hline
\end{tabular}

Keterangan: S1: Highly suitable category; S2: Suitable category; N: Less suitable category Sumber: (Rositasari, Rachma, Nurhati, Purbonegoro, \& Yogaswara, 2017) and (Jamaluddin, Syam, Mustarin, \& Rivai, 2020)

\section{Analisis Tapak}

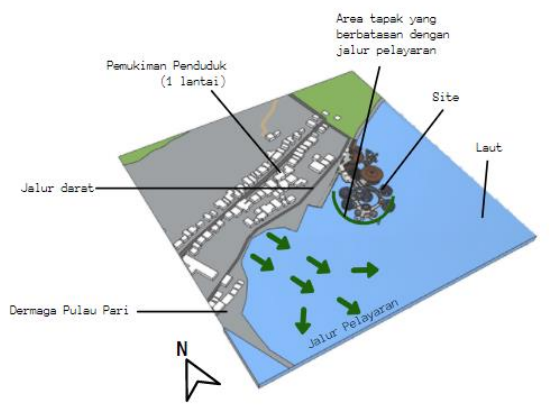

Gambar3. Analisis Tapak

Sumber: Dokumentasi Pribadi

Analisis tapak dilakukan dengan mempelajari kondisi alam di sekitar tapak dan menjadi pertibangan dalam menempatkan program dalam bangunan sekaligus bentuk massa yang harus dihasilkan. Cahaya matahari dari pukul 06.00-16.00 dimanfaatkan semaksimal mungkin untuk penerangan ruangan dalam bangunan, pembangkit listrik tenaga surya, dan mengeringkan rumput laut dengan cara memposisikan massa agar tidak tertutup bayang-bayang massa lain. Bagian barat tapak juga berbatasan dengan jalur pelayaran Pulau Pari dengan view dermaga yang kurang menarik, sehingga program di sebelah barat dijadikan area industri pengolahan rumput laut. Sedangkan bagian timur dijadikan area wisata dan restoran yang bisa dinikmati pengunjung karena mendapat view laut lepas. Area timur juga menjadi area penanaman rumput laut bebas karena tidak mengganggu jalur pelayaran dan mendapat air bernutrisi dari laut lepas. Sedangkan sisi utara yang berbatasan dengan darat dijadikan area penerimaan dan service kawasan. Pembagian program seperti ini juga memungkinkan alur industri bergerak satu arah untuk efisiensi, sedangkan alur pengunjung dan wisata tetap dua arah. 


\section{Gubahan Massa}

Metode desain biomorfik diwujudkan dalam pengolahan bentuk gubahan massa yang mengimplementasikan morfologi rumput laut, yaitu holdfast, stipe, dan blade. Holdfast diibaratkan sebagai pondasi tiang pancang yang mengikat bangunan ke dasar laut. Stipe diibaratkan sebagai titik pusat kawasan yang mengikat massa. Sedangkan blade dan gas bladder diwujudkan dalam pembentukan massa dan disesuaikan dengan kebutuhan ruang tiap fungsi. Pengolahan denah dan tampak juga didominasi unsur lengkung yang tidak menentu agar bangunan terlihat organik seperti rumput laut. Proses desain gubahan massa dapat dilihat pada gambar berikut ini.

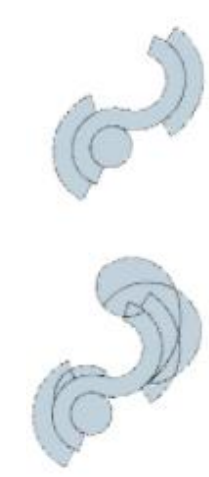

Program

Industri
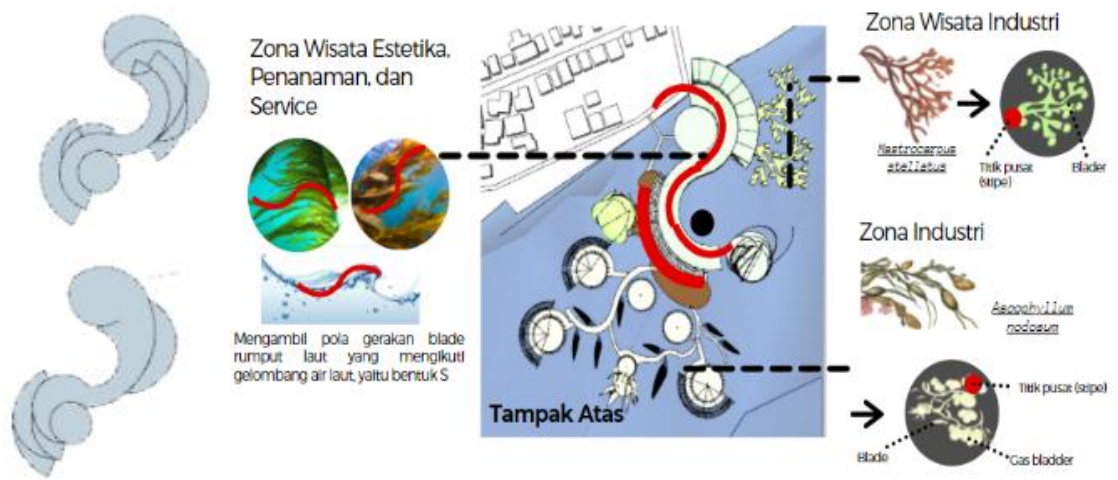

Gambar 4. Proses Pembentukan Massa

Sumber: Dokumentasi Pribadi, 2021
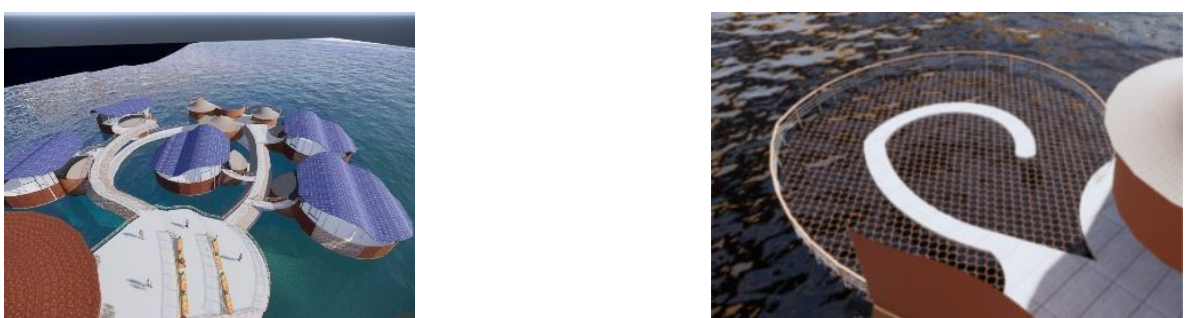

Gambar 5. Perspektif Eskterior Area Industri dan Area Jemur Rumput Laut Sumber: Dokumentasi Pribadi, 2021

Jenis rumput laut yang digunakan adalah Eucheuma cottoni dan Sargassum.sp karena memiliki nilai ekonomis yang tinggi dan sudah dibudidayakan oleh nelayan di Pulau Pari. Pulau Pari memproduksi $16.600 \mathrm{~kg}$ rumput laut per tahun dengan kisaran waktu 6-8 minggu per panen. Artinya, rumput laut yang dihasilkan dalam satu kali panen berkisar $2.766 \mathrm{~kg}$. Jumlah ini masih dapat meningkat bila banyak nelayan yang tertarik untuk melakukan budidaya rumput laut. Rumput laut mentah yang masuk ke dalam proyek akan diolah melalui serangkaian proses dengan tenaga manusia maupun mesin menjadi produk.

Proses industri dimulai dari dermaga dalam tapak untuk memasukkan rumput laut dari nelayan. Disediakan area cuci rumput laut dengan jumlah kolam dihitung agar seluruh rumput laut segar dapat segera dicuci dan diproses sebelum membusuk ( 2 hari). Kemudian berlanjut ke proses penjemuran secara horizontal dan ruang pemotongan rumput laut.

Setelah melalui proses pengolahan tahap awal, rumput laut dimasukkan ke workshop industri sesuai fungsinya masing-masing untuk diolah menjadi produk sehari-hari. Jenis workshop terdiri dari material bangunan, plastik, kertas, pupuk dan furniture. Bentuk gubahan massa area industri adalah bulat agar pekerja memiliki ruang bekerja yang terbuka dan efektif. Pola tata 
letak mesin dalam bangunan dimulai dari proses tahap awal hingga tahap akhir yang disusun searah jarum jam. Pada workshop furniture, pembagian ruangan terdiri dari area pembuatan adonan, cetak furniture, pembakaran, finishing, dan pengemasan. Workshop kertas terdiri dari area pembuatan pulp, bleaching dan cetak pulp, penirisan air kertas, jemur, finishing, dan pengemasan. Workshop material bangunan terdiri dari area pencampuran bahan semen, pencampuran bahan bata, cetak bata, jemur bata, pembuatan panel atap, dan pengemasan. Workshop plastik terdiri dari area pencampuran dan perebusan adonan plastik, cetak, jemur, dan pengemasan. Sedangkan workshop pupuk terdiri dari area pencampuran bahan, fermentasi pupuk cair/padat, dan pengemasan. Seluruh area industri dikelilingi dinding untuk mencegah angin dan air laut masuk dan membuat peralatan berkarat. Namun, bagian atas dinding dibuat terbuka agar udara dan cahaya alami dapat masuk dan menerangi area kerja.

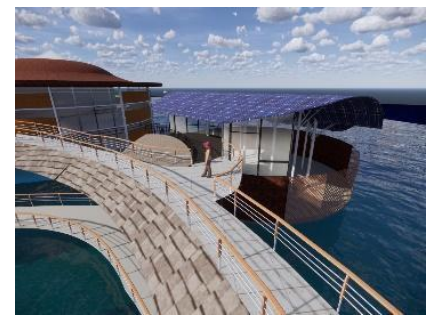

Gambar 6. Perspektif Eksterior dan Interior Kawasan Industri

Sumber: Dokumentasi Pribadi, 2021

Produk yang sudah dikemas, selanjutnya dibawa ke area parkir gerobak industri untuk dibawa ke luar tapak dan didistribusikan ke masyarakat maupun luar pulau melalui jalur penghubung area industri selebar 2.5 meter yang terbuka agar pekerja bisa merasakan keterbukaan dan kesatuan dengan alam untuk relaksasi sekaligus diingatkan oleh kekuatan alam. Wisatawan juga dapat melihat proses industri melalui jembatan di atas jalur area industri yang menghubungkan area estetika, toko suvenir, dan area pengamatan di workshop industri. Jembatan tersebut bukan hanya berperan sebagai sirkulasi, namun juga sebagai area refleksi agar pengunjung bisa menikmati pemandangan, dan penutup agar kegiatan industri tidak terkena hujan.

Kegiatan industri membutuhkan air bersih dan listrik untuk mengoperasikan peralatan. Untuk menghemat energi, listrik diambil panas matahari yang ditangkap oleh panel surya di atas atap workshop. Energi panas diubah menjadi listrik melalui inverter yang dipasang di setiap workshop. Sedangkan air bersih didapat dengan pengolahan air laut menjadi air tawar dengan sistem Sea Water Reverse Osmosis (SWRO). Meski begitu, tersedia pula listrik dari PLN dan air dari PAM sebagai cadangan.

\section{Wisata Estetika}
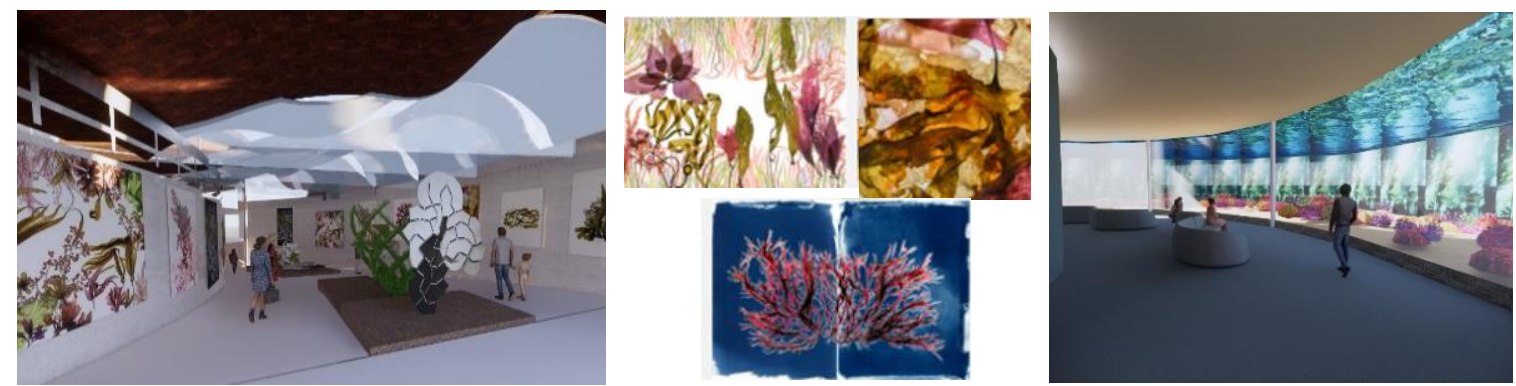

Gambar 7. Galeri dan Aquarium Rumput Laut

Sumber: Dokumentasi Pribadi, 2021 
Masyarakat dan pengunjung sudah terbiasa memandang rumput laut sebagai objek atau sekedar manfaatnya saja. Oleh karena itu, program wisata estetika harus bisa menuntun pengunjung secara bertahap untuk membuang cara memandang rumput laut sebagai objek dan menikmati keindahan dan eksistensinya. Penghayatan estetika berpedoman pada buku 'How we understand art: A cognitive developmental account of aesthetic experience', sehingga terbagi atas 5 tahapan.

Tahap favoritism berupa galeri rumput laut yang berperan sebagai aesthetic stimuli. Interior dihias dengan instalasi rumput laut (baik 2D maupun 3D) yang tidak memiliki makna dan bertujuan sebagai pengantar dari cara berpikir antroposentris ke alam.

Tahap beauty and realism diwujudkan dalam program aquarium rumput laut, yaitu pengunjung dibawa ke ruangan 4 meter di bawah permukaan laut dan bisa melihat langsung rumput laut yang hidup dan tumbuh di sekitar tapak melalui kaca. Desain ruangan membawa manusia untuk memandang rumput laut sebagai subjek, agar pengunjung seolah bisa berkenalan dengan 'teman baru' mereka. Proses berkenalan tidak lepas dari interaksi menggunakan panca indra, seperti mengenal nama dan jenisnya, memandang wujud rumput laut, mendengarkan suara, melihat gerakannya, dan lain-lain.
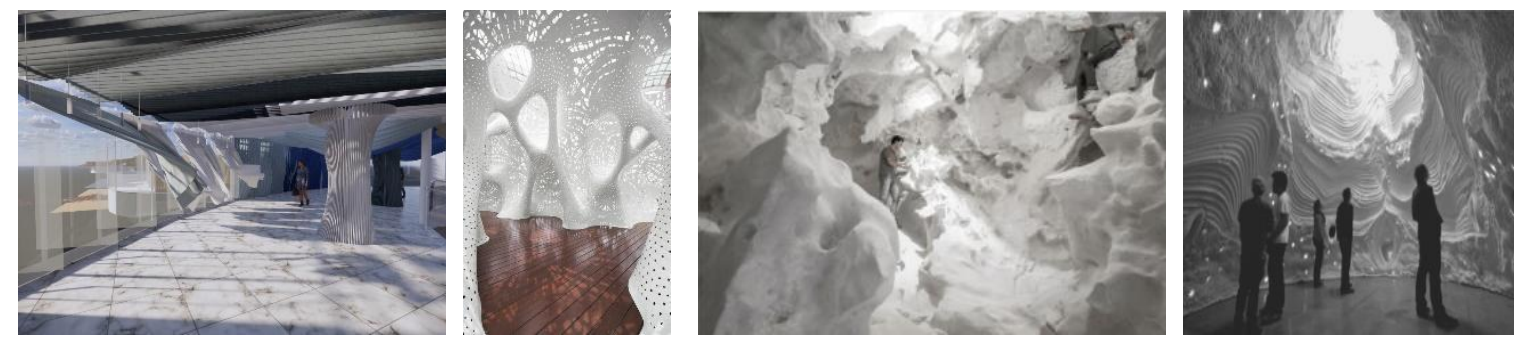

Gambar 8. Penghayatan Gelombang, Cahaya, dan Waktu Sumber: Dokumentasi Pribadi, archdaily.com, 2021

Tahap expressiveness mengajak pengunjung untuk melihat/merasakan hal yang dialami rumput laut di alam semesta dan interaksinya dengan individu lain, diwujudkan dalam ruang penghayatan gelombang laut dan cahaya matahari. Pada ruang penghayatan gelombang laut, lantai, dinding, dan plafon dibuat bergelombang sehingga pengunjung dapat merasa ruangan bergerak ketika berjalan ditengah tengahnya. Pada ruang penghayatan cahaya matahari, dinding dan plafon dibuat berlubang agar dapat memberikan kesan cahaya yang masuk dari selasela rumput laut yang mengapung di permukaan air.

Tahap style and form mengajak manusia dan rumput laut menempuh mesin waktu untuk melihat perkembangan rumput laut dari bibit hingga dewasa. Interior ruang awalnya dibuat sepi, seolah rumput laut masih berupa bibit/populasinya sedikit. Namun seiring pengunjung berjalan, ruangan semakin padat dengan instalasi yang menghimpit pengunjung, seolah populasi rumput laut meningkat.

Tahap autonomy atau self-reflect berupa ruang terbuka dan luas dengan view ke arah laut dari atas, sehingga manusia bisa merasa sendirian, hanya ada dirinya dan alam semesta. Ego manusia yang sudah ditanggalkan dari proses sebelumnya, sehingga manusia dapat merefleksikan bahwa dirinya hanyalah sebagian kecil dari alam semesta. Pada akhir tahap estetika, pengunjung terhubung ke toko suvenir dan area penerimaan pada kawasan. 


\section{Area Penerimaan}
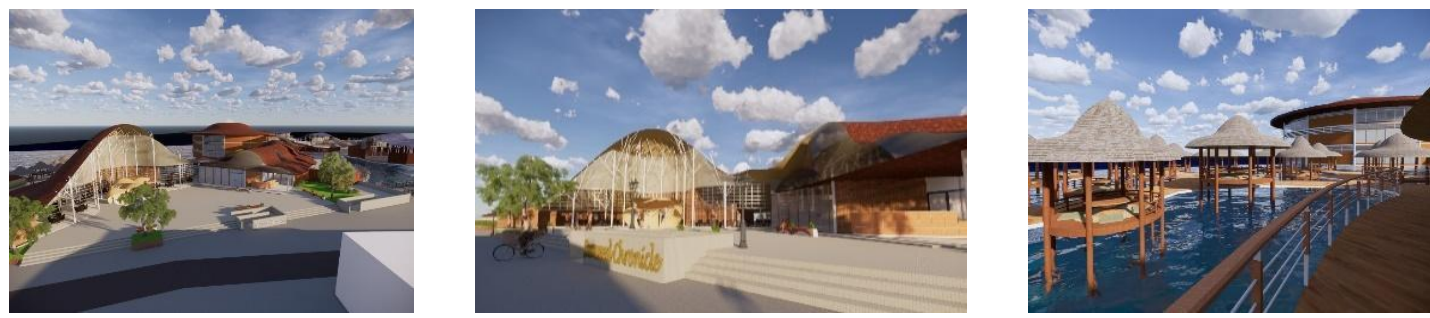

Gambar 9. Perspektif Eksterior Area Penerimaan dan Restoran

Sumber: Dokumentasi Pribadi, 2021

Program industri dan estetika dihubungkan dengan area penerimaan yang terletak di bagian utara dan berbatasan dengan daratan, dan juga berperan sebagai 'wajah' bangunan. Area penerimaan berfungsi sebagai ruang publik bagi masyarakat maupun wisatawan dengan berbagai fasilitas seperti area duduk, panggung edukasi, kios penjualan hasil rumput laut, dan restoran. Kolom pada area penerimaan dibuat bercabang untuk menciptakan kesan berada di bawah rumput laut yang bergoyang. Plafon dibuat tinggi agar memberi kesan luas dan menerima pengunjung. Area penerimaan juga dibuat terbuka agar pengunjung bisa masuk dari segala arah. Untuk faktor keamanan pada malam hari, area pintu masuk dapat ditutup dan dikunci dengan sliding door. Pengudaraan dan pencahayaan alami masuk melalui dinding terbuka yang dilapisi teralis dan sebagian kaca di beberapa tempat untuk mencegah air hujan masuk.

\section{Material}

Material yang digunakan pada proyek didominasi dengan rumput laut. Struktur yang digunakan adalah beton yang dicampur dengan rumput laut untuk meningkatkan kekokohan, ketahanan terhadap air, sekaligus mengurangi kadar karbon. Kolom bercabang pada area penerimaan menggunakan struktur baja yang disambung dengan kolom beton. Atap proyek menggunakan panel rumput laut yang dilapis karet agar memastikan ketahanan terhadap air hujan. Material dinding sebagian menggunakan bata rumput laut, terutama ruang service dan privat. Sedangkan area toko suvenir menggunakan dinding bambu. Karena berada di atas air dengan jarak 4 meter dari dasar laut, bangunan ditumpu dengan pondasi tiang pancang dengan ketinggian $60 \mathrm{~cm}$ dari daratan untuk mencegah bangunan terendam air saat pasang.

\section{KESIMPULAN DAN SARAN Kesimpulan}

Dalam perancangan proyek Seaweed Chronicle (An Industrial and Aesthetic Hybrid Program), Pulau Pari dipilih sebagai lokasi perancangan karena memiliki luas lahan budidaya rumput laut yang tinggi, memiliki masalah dari segi manusia dan alam, serta memiliki peluang untuk berkembang. Tapak terpilih berada di dekat Dermaga Pulau Pari, tidak mengganggu zona pelayaran dan wisata, namun terletak diantara keduanya sehingga berpotensi menghubungkan program.

Program industri mendorong produksi barang kebutuhan sehari-hari dari rumput laut (kertas, plastik, material bangunan, furniture, pupuk), sehingga meningkatkan minat masyarakat untuk menanam rumput laut. Semakin banyak rumput laut yang ditanam berarti semakin banyak karbon yang diserap dari lingkungan, sehingga bisa menyelesaikan permasalahan alam di Teluk Jawa. Sedangkan program estetika berfungsi sebagai daya tarik wisatawan sekaligus memberi pemahaman bahwa rumput laut bukan hanya objek yang bisa diperbudak, melainkan setara dengan manusia dan harus dihargai, dengan harapan dapat mengubah pola pikir masyarakat untuk lebih mencintai alam dan mengubah kebiasaan yang merusak lingkungan. 
Material dalam bangunan juga dipilih agar sebisa mungkin memanfaatkan rumput laut untuk mengurangi karbon di alam. Desain bukaan dan dinding dibuat agar dapat memasukkan pencahayaan dan pengudaraan alami mungkin ke dalam bangunan semaksimal untuk menghemat energi. Sumber listrik dan air untuk proses industri juga berasal dari alam, yaitu panel surya dan SWRO.

\section{Saran}

Dalam merancang proyek, terutama bagian industri, penulis hanya menyediakan pengolahan rumput laut menjadi kertas, pupuk, plastik, material bangunan, dan furniture berdasarkan studi pustaka manfaat rumput laut yang dikaji penulis. Oleh karena itu, proyek masih terbuka untuk peninjauan jenis produk yang lebih beragam dari rumput laut.

\section{REFERENSI}

Chung, I. K., Oak, J. H., Lee, J. A., Shin, J. A., Kim, J. G., \& Park, K.-S. (2013). Installing Kelp Forests/Seaweed Beds for Mitigation and Adaptation Against Global Warming: Korean Project Overview. ICES Journal of Marine Science, 1038-1044.

Dahuri, R. (2005). Potensi Ekonomi Kelautan. Republika.

Damarjati, D. (2019). Kunci BBM dan Bahan Pokok Satu Harga di Kepulauan Seribu. news.detik.com.

Dove, C. A. (2014). The Development of Unfired Earth Bricks Using Seaweed Biopolymers . WIT Transactions on Ecology on The Built Environment, Vol 142, 219-230.

Frick, H. (2006). Arsitektur Ekologis. Yogyakarta: Kanisius.

Gewati, M. (2019). Begini Cara Kepulauan Seribu Jadi Produsen Rumput Laut Kelas Dunia. Kompas.com.

Hoogvliet, N. (2018). Seaweed Re-search . The Hague: Studio Nienke Hoogvliet.

Iselin, J. (2019). The Curious World of Seaweed. California: Heyday Books.

Jamaluddin, Syam, H., Mustarin, A., \& Rivai, A. A. (2020). Spatial Multi-Criteria Approach For Determining The Cultivation Location Of Seaweed Eucheuma Cottonii in Takalar Regency, South Sulawesi, Indonesia. Aquaculture, Aquarium, Conservation \& Legislation - International Journal of the Bioflux Society., 1413-1430.

Larsen, K. (2018). Seaweed Thatch Reimagined. Guldbergsgade: Kobenhavns Erhvervsakademi. NiputuDK. (2015). Budidaya Rumput Laut Dengan Metode Apung Standar Better Management Practices (BMP). Medan.

N'Yeurt, A. d., Chynoweth, D. P., Capron, M. E., Stewart, J., \& Hasan, M. A. (2012). Negative Carbon Via Ocean Afforestation. Process Safety and Environmental Protection, 467474.

Parsons, M. J. (1987). How We Understand Art: A Cognitive Developmental Account of Aesthetic Experience. New York: Cambridge University Press.

Putri, G. R. (2019). Karakterisasi Bioplastik dari Rumput Laut (Eucheuma cottonii). Risenologi (Jurnal Sains, Teknologi, Sosial, Pendidikan, dan Bahasa) Volume 4 Issue 2, 59-64.

Rositasari, R., Rachma, P., Nurhati, I. S., Purbonegoro, T., \& Yogaswara, D. (2017). 5 Dekade LIPI di Teluk Jakarta. Jakarta: Lembaga Ilmu Pengetahuan Indonesia Puslit Oseanografi .

Sedayu, B. B., Erawan, I. M., \& Assadad, L. (2014). Pupuk Cair dari Rumput Laut Eucheuma cottonii, Sargassum sp. dan Gracilaria sp. Menggunakan Proses Pengomposan. Jurnal Pascapanen dan Bioteknologi Kelautan dan Perikanan, 61-68.

Siddique, M. N., \& Wahid, Z. b. (2017). Effect of mixing proportion on the properties of seaweed modified sustainable concrete. The 2 nd International Conference on Applied Science and Technology 2017 (ICAST'17). 
Suparmi, \& Sahri, A. (2009). Mengenal Potensi Rumput Laut : Kajian Pemanfaatan Sumber Daya Rumput Laut dari Aspek Industri dan Kesehatan. Sultan Agung Vol XLIV No. 118, 96-116.

Wibowo, A. (2019). Rumput Laut, Komoditas Penting Yang Belum Dioptimalkan. Balai Besar Pengujian Penerapan Produk Kelautan dan Perikanan.

You, C. H. (2008). Partnership Opportunity in Developing Pulp \& Paper Industry. Seaweed International Business Forum and Exhibition II-Makassar. Jakarta: Departemen Kelautan dan Perikanan. (2021). Hasil Sensus Penduduk 2020. Badan Pusat Statistik. 